\title{
Preprofessional Cultivation Strategies for English Competencies of Elementary School Versatile Teachers under Rural Vitalization
}

\author{
Huijun Fu1, Ying Huang ${ }^{2}$ \\ ${ }^{1}$ College of Foreign Language Education and International Business, Baoding University, Baoding, China \\ ${ }^{2}$ Office of Research Affairs, Baoding University, Baoding, China \\ Email: fuhuijun@bdu.edu.cn
}

How to cite this paper: Fu, H. J., \& Huang, Y. (2021). Preprofessional Cultivation Strategies for English Competencies of Elementary School Versatile Teachers under Rural Vitalization. Open Journal of Modern Linguistics, 11, 226-235.

https://doi.org/10.4236/ojml.2021.112018

Received: March 29, 2021

Accepted: April 19, 2021

Published: April 22, 2021

Copyright $\odot 2021$ by author(s) and Scientific Research Publishing Inc. This work is licensed under the Creative Commons Attribution International License (CC BY 4.0).

http://creativecommons.org/licenses/by/4.0/

(c) (i) Open Access

\begin{abstract}
As socialism with Chinese characteristics has entered a new era, rural vitalization is an important national strategy for China. The vitalization of education is an important part of rural vitalization. Cultivating versatile teachers for elementary schools can improve the quality of rural teaching, so as to promote rural vitalization from the educational aspect. As English teaching is a weak part in rural education, the study focuses on the preprofessional cultivation strategies for English competencies of elementary school versatile teachers. By means of quantitative and qualitative studies, the study reveals some problems in preprofessional cultivation of English competencies, then puts forward preprofessional cultivation strategies from aspects of teaching objectives, curriculum, professional training and assessment methods. It is hoped that the study can provide effective suggestions as well as practical guidance for the preprofessional cultivation of English competences of elementary school versatile teachers under the strategy of rural vitalization.
\end{abstract}

\section{Keywords}

Rural Vitalization, Elementary School Versatile Teachers, English

Competencies, Preprofessional Cultivation

\section{Introduction}

As an important strategic decision, the rural vitalization strategy was first proposed by President Xi Jinping in the Report to the 19th CPC National Congress (Xi, 2017). The Report pointed out "Issues relating to agriculture, rural areas, and rural people are fundamental to China as they directly concern our country's stability and our people's wellbeing. Addressing these issues should have a 
central place on the work agenda of the Party". The strategy of rural vitalization is an important aspect to develop the modernized economy. At the same time, the development of education can drive social and economic progress.

Education is an important approach to rural vitalization. On February 4, 2018, China released a package of policies under the "No. 1 central document" (The Central Committee of the Communist Party of China (CPC) and the State Council, 2018c) charting the roadmap for the country's rural vitalization strategy. The "No. 1 central document" lays emphasis on giving priority to develop education in rural areas. It suggests to attach great importance to the development of compulsory education, and promote the establishment of a compulsory education development mechanism whereby urban areas lead rural areas, and the development of urban and rural areas is integrated and balanced. The country should coordinate the allocation of teachers in urban and rural areas, and give preference to rural areas to build a strong contingent of rural teachers. Besides, National Rural Vitalization Strategic Plan (2018-2022) (The Central Committee of the Communist Party of China (CPC) and the State Council, 2018b) pointed out that priority should be given to the development of rural education and the country should promote public education resources to be allocated to rural areas.

Versatile teachers of rural elementary schools are a special group. Different from teachers of specific subjects, versatile teachers should master the basic knowledge and skills of education and teaching, possess reasonable structures of subject knowledge and ability, and have the independent ability to assume the teaching tasks of all the elementary school courses. Meanwhile, they can also undertake teaching research and management of elementary schools. In the cultivation of versatile teachers for elementary schools, English competencies should not be ignored, as it plays an important role in promoting the quality of rural elementary education.

\section{Literature Review}

The "No. 1 central document" (The Central Committee of the Communist Party of China (CPC) and the State Council, 2018c) issued by the Central Committee of the Communist Party of China (CPC) and the State Council states to pool the strength of the whole society and strengthen the support of rural revitalization talents. The country should promote "county administration and school recruitment" of rural teachers. It will implement the plan to support talents in remote and underdeveloped areas, border areas with ethnic minorities, and old revolutionary base areas. It will continue to implement the "Three Support and One Assistance" plan and the plan to provide teachers with special posts. The country will organize and implement the grass-roots development plan for college graduates. It will support local institutions of higher learning and vocational colleges in making full use of education and training resources, setting up specialties in a flexible manner, and innovating personnel training models so as to train specialized personnel for rural vitalization. 
In order to optimize the ranks of rural teachers and improve the quality of rural education, the education authority in Hebei issued A Notice on the Implementation of the Training of Versatile Teachers in Rural Elementary Schools in 2019. In Feb. 2020, Baoding Education Bureau and other three departments jointly issued the Implementation Plan for Government-supported Training of Elementary School Versatile Teachers in Baoding. Relying on Baoding University and focusing on the major of elementary school education, the plan aims to cultivate 100 versatile teachers in order to support rural elementary schools and teaching sites in remote and underdeveloped areas.

Through searching on CNKI (China National Knowledge Infrastructure), at present there are 6 domestic papers on the cultivation of elementary school versatile teachers under the rural vitalization strategy, but no papers abroad. Yu \& Yang (2018) analyzed the psychological problems of preprofessional versatile teachers and put forward optimization suggestions from the policy level. Yang (2019) analyzed the problems existing in curriculum setting in Ji Shou University and put forward the integration of courses. Guo, Tian, \& Zheng (2019) analyzed the change of roles and functions of elementary school versatile teachers, and made a new orientation of them. Chen \& Liao (2019) conducted a study on the pre-, mid-and post-stage of the targeted training of elementary school versatile teachers at public expense. Xiao \& Wu (2020) investigated problems existed in the cultivation of versatile teachers in Ji'an Vocational and Technical College through a questionnaire, and put forward the preprofessinal cultivation strategies. Sun \& Wen (2020) discussed the practical needs of versatile teachers of rural elementary schools and the localized training strategies of versatile teachers.

To sum up, the current studies has made a preliminary exploration to the cultivation of versatile teachers of elementary schools under the rural vitalization strategy. However, most of the studies are from the macroscopic point of view. There's no study focusing on the preprofessional cultivation of English competencies of versatile teachers under the rural vitalization strategy. Meanwhile, Baoding University is authorized to recruit the first elementary school versatile teachers in 2020. The cultivation of versatile teachers is in the early stage. Therefore, the study in this field is quite urgent.

\section{Methodology}

In this part, the research questions, research participants, research instruments, as well as data collection and analysis are introduced.

\subsection{Research Questions}

The study aims to realize that the cultivation of talents could meet the demand of rural vitalization. It also aims to improve the English teaching skills and enrich English teaching experience of versatile teachers of elementary schools in the preprofessional cultivation period. The application of preprofessional cultivation strategies aims to ensure the quality of rural basic education in the future. Based on the purpose of the study, the following two research questions are put 
forward:

1) To investigate the requirements of rural vitalization for elementary school versatile teachers.

2) To investigate the status quo of preprofessional English competencies of elementary school versatile teachers.

Through the investigations, it is hoped that the cultivation of preprofessional English competencies of versatile teachers will become more professional, thus promoting the development of the overall preprofessional abilities of elementary school versatile teachers.

\subsection{Research Participants}

Altogether 100 freshmen from two classes of Baoding University joined the research. Their major is elementary school education. Each class has 50 students. They are between the ages of 18 and 20. All of them have learned English at least 6 years. The respondents will receive full-time education, and they are directed students. After graduation, they'll become versatile teachers of elementary schools in remote and underdeveloped rural areas.

\subsection{Research Instruments}

The research instruments employed in this study include standardized test paper, questionnaire, and interview.

First, the standardized test paper is the English section of China's national college entrance exam for 2020. Researchers first analyzed the test results of the 100 respondents. The test analysis aims to grasp respondents' English proficiency.

Second, 100 copies of questionnaire were distributed to all the respondents. The questionnaire includes altogether 12 items in the purpose of investigating the status quo of the preprofessional English competencies of elementary school versatile teachers and whether the preprofessional English competencies could meet the demand of rural fundamental education and rural vitalization. The questionnaire can also reveal the problems existed in the cultivation of preprofessional English competencies. It is adopted in the form of the Likert scale, the five choices of which are arranged in the following way: A = always; $\mathrm{B}=$ usually; $\mathrm{C}=$ sometimes $\mathrm{D}=$ seldom; $\mathrm{E}=$ never.

Third, an interview was carried out among 35 respondents after the application of cultivation strategies. In order to ensure the objectivity of the research, all the respondents were voluntary. Besides, the whole process of the interview was recorded. After the interview, researchers checked the interview result based on the recording.

\subsection{Data Collection and Analysis}

The research group successively sorted out and collected the English scores of the national college entrance exam, the questionnaire and the interview. The research results and related analyses are as follows: 
Table 1 shows the results of English in national college entrance exam for 2020.

According to Table 1, each class has 50 students. The English total score in national college entrance exam is 150 . The mean score of Class 1 is 111.56 , while that of Class 2 is 111.12 , so the grades of the two classes have no great difference. In both classes, the proportions of high score (130 - 139) and low score (80 - 89) are relatively low. Scores above the average (120 - 129) account for $20 \%$ and $26 \%$ respectively. The number of students with medium scores $(100-119)$ is high, accounting for 58\% in Class 1 and 54\% in Class 2. At the same time, the number of students with scores from 90 to 99 accounting for $10 \%$ in each class. It can be seen from the above data that students' grades are in normal distribution. On the whole, students have grasped basic English knowledge in high school. However, the level of their English knowledge is expected to get promoted especially for students with scores below 100. In general, their English grades are below that of students majoring in English. Therefore, as future versatile teachers of rural elementary schools, their English competencies are expected to get enhanced during the college period of study.

Table 2 shows the status quo of preprofessional English competencies of elementary school versatile teachers.

Items 1 to 3 are designed to investigate the preprofessional English language competency of versatile teachers of elementary schools. Item 1 shows most respondents (34 always, 57 usually) can acquire English language points in the textbook. However, a small number of respondents (8 sometimes, 1 seldom) have difficulty, because they are weak in the study of basic English knowledge. Item 2 shows some respondents (11 seldom, 5 never) don't pay attention to practicing English pronunciation and intonation. While in Item 3, 16 respondents seldom express opinions in English. As the future elementary school teachers in rural areas, teachers' oral English will directly affect pupil's English learning, so practicing good oral English is quite necessary for communication.

Item 4 and Item 5 can reflect the respondents' cultural awareness and thinking ability. The result of Item 4 is not optimistic. Only 10 respondents always think the cultural connotations of a passage. Most respondents (44 sometimes, 13 seldom, 2 never) lack this awareness. The data of Item 5 show that 18 respondents seldom subconsciously compare English culture with Chinese culture and 1 respondent chose "never". English study is not only the study of language, but also the study of cultures. Through thinking and comparison, respondents can deeply

Table 1. The results of English in national college entrance exam for 2020.

\begin{tabular}{|c|c|c|c|c|c|c|c|c|}
\hline $\begin{array}{l}\text { Class } \\
(\mathrm{N})\end{array}$ & $\begin{array}{l}\text { Total } \\
\text { Score }\end{array}$ & Mean & $\begin{array}{c}130-139 \\
\%(\mathrm{~N})\end{array}$ & $\begin{array}{c}120-129 \\
\%(\mathrm{~N})\end{array}$ & $\begin{array}{c}110-119 \\
\%(\mathrm{~N})\end{array}$ & $\begin{array}{c}100-109 \\
\%(N)\end{array}$ & $\begin{array}{l}90-99 \\
\%(N)\end{array}$ & $\begin{array}{l}80-89 \\
\%(N)\end{array}$ \\
\hline $\begin{array}{c}\text { Class } 1 \\
(50)\end{array}$ & 150 & 111.56 & $6(3)$ & $20(10)$ & $40(20)$ & $18(9)$ & $10(5)$ & $6(3)$ \\
\hline $\begin{array}{c}\text { Class } 2 \\
(50)\end{array}$ & 150 & 111.12 & $4(2)$ & $26(13)$ & $30(15)$ & $24(12)$ & $10(5)$ & $6(3)$ \\
\hline
\end{tabular}


Table 2. A questionnaire on the status quo of preprofessional English competencies of elementary school versatile teachers.

\begin{tabular}{|c|c|c|c|c|c|}
\hline Items & $\begin{array}{c}\text { A } \\
\text { always }\end{array}$ & $\begin{array}{c}\text { B } \\
\text { usually }\end{array}$ & $\begin{array}{c}\mathrm{C} \\
\text { sometimes }\end{array}$ & $\begin{array}{c}\mathrm{D} \\
\text { seldom }\end{array}$ & $\begin{array}{c}\mathrm{E} \\
\text { never }\end{array}$ \\
\hline 1. Acquire English language points in the textbook. & 34 & 57 & 8 & 1 & 0 \\
\hline 2. Practice English pronunciation and intonation. & 9 & 40 & 35 & 11 & 5 \\
\hline 3. Express opinions in English. & 7 & 36 & 41 & 16 & 0 \\
\hline 4. Think the cultural connotations of a passage. & 10 & 31 & 44 & 13 & 2 \\
\hline $\begin{array}{l}\text { 5. Subconsciously compare English culture with } \\
\text { Chinese culture. }\end{array}$ & 12 & 30 & 39 & 18 & 1 \\
\hline 6. Study English autonomously. & 17 & 41 & 40 & 2 & 0 \\
\hline 7. Finish English teaching design. & 26 & 45 & 21 & 8 & 0 \\
\hline 8. Understand English pedagogy. & 15 & 44 & 32 & 9 & 0 \\
\hline 9. Make English courseware and mini-lecture. & 22 & 33 & 34 & 10 & 1 \\
\hline 10. Practice English teaching. & 9 & 29 & 39 & 22 & 1 \\
\hline $\begin{array}{l}\text { 11. Watch documentaries on excellent rural English } \\
\text { teachers. }\end{array}$ & 11 & 21 & 37 & 30 & 1 \\
\hline $\begin{array}{l}\text { 12. Note the development of English education in } \\
\text { rural elementary schools. }\end{array}$ & 12 & 30 & 46 & 12 & 0 \\
\hline
\end{tabular}

understand different cultures. Meanwhile, their thinking ability will be strengthened.

Item 6 is designed to investigate the status of students' learning ability. Although almost all the respondents have the consciousness of English autonomous learning, 40 respondents chose "sometimes" and 2 respondents chose "seldom". Cultivating autonomous learning ability is quite necessary. As the respondents will work in rural areas, they should update their knowledge through autonomous learning in most cases. Possessing autonomous learning ability is beneficial to the future teaching and scientific research.

Items 7 to 10 aim to investigate the status quo of preprofessional English teaching skills of elementary school versatile teachers. In Item 7, 29 respondents (21 sometimes, 8 seldom) have certain difficulty in finishing English teaching design. In Item 8 , the shocking data attract researchers' attention. 41 respondents (32 sometimes, 9 seldom) should increase their understanding of English pedagogy. The result of Item 9 is also not satisfactory. Only more than a half of respondents (22 always, 33 usually) can make English courseware and mini-lectures. Item 10 shows that respondents' practice of English teaching is not enough, as 39 respondents chose "sometimes", 22 chose "seldom" and 1 chose "never". Items from 7 to 10 are major contents of cultivating qualified versatile teachers of elementary schools. Therefore, these items are worth attention. Students should grasp English pedagogy and some basic English teaching skills during university learning period.

Items 11 and 12 are designed to investigate whether the respondents have 
education feel or not. The data of Item 11 show that 30 respondents seldom watch documentaries on excellent rural English teachers, and 1 respondent never. In Item 12, 46 respondents note the development of English education in rural elementary schools sometimes, while 12 respondents seldom do that. As the future teachers of elementary schools, students should inherit educational traditions from excellent rural English teachers, develop teaching enthusiasm and contribute to rural English education.

Table 3 is an interview after the application of preprofessional cultivation strategies for English competencies. The feedback of 35 respondents can examine the effect of the cultivation strategies.

Researchers are satisfied with the result of Question 1 as all the 35 respondents have acquired more English knowledge. In Question 2, 31 respondents have improved their English listening, speaking, reading and writing skills. However, 4 respondents chose "no". As English learning is a gradual process, the English skills can be further enhanced through more practice. Question 3 shows 27 respondents think more about the cultural value of a passage. 8 respondents haven't realized the importance of culture study, so their cultural awareness should get further cultivated. In Question 4, most respondents have grasped more English teaching skills. 2 respondents disagree. Teachers should offer students room to develop their teaching skills. Question 5 shows 32 respondents are willing to devote themselves to rural English education. As their future careers are versatile teachers of rural elementary schools, students should be educated to love their future jobs and possess noble morality. In general, the results of the interview are satisfactory. Besides, researchers have discussed the results and further improved the preprofessional cultivation strategies.

Table 3. An interview after the application of preprofessional cultivation strategies for English competencies.

\begin{tabular}{lcc}
\hline Questions & Feedbacks \\
\cline { 2 - 3 } & Yes & No \\
\hline 1. Have you acquired more English knowledge? & 35 & 0 \\
2. Have you improved your English listening, speaking, reading and writing skills? & 31 & 4 \\
3. Do you think more about the cultural value of a passage? & 27 & 8 \\
4. Have you grasped more English teaching skills? & 33 & 2 \\
5. Are you willing to devote yourself to rural English education? & 32 & 3 \\
\hline
\end{tabular}

\section{Suggestions}

The Opinions of the CPC Central Committee and the State Council on Comprehensively Deepening the Reform of Teaching Staff Construction in the New Era (The Central Committee of the Communist Party of China (CPC) and the State Council, 2018a) clearly points out that a powerful education requires powerful teachers first, and teachers' competencies directly determines the success 
or failure of the cultivation of students' competencies. Therefore, in order to promote teachers' competencies, the preprofessional cultivation of elementary school versatile teachers is crucial. Based on the above investigations, there are several suggestions as to the preprofessional cultivation strategies for English competencies of elementary school versatile teachers under rural vitalization.

First, in terms of teaching objectives, the preprofessional cultivation of English competencies of elementary school versatile teachers should focus on the instrumental and humanistic characteristics. On one hand, English teaching should realize the imparting of English knowledge, the cultivation of students' language skills, and the promotion of students' listening, speaking, reading, writing and translating abilities. On the other hand, English teaching should focus on the exploration of rich cultural meanings of English textbooks, the inspiration of students' spiritual world, and the cultivation of students' various abilities, such as intercultural communicative ability, critical thinking ability and innovative thinking ability. Besides, as students will work in rural areas after graduation, the teaching objectives also involve the promotion of English teaching and research ability, the mastery of western pedagogy and psychology theory, and the shaping of teachers' professional ethics. Meanwhile, guiding students to realize the importance of English teaching in rural areas and helping them build confidence in English teaching should also be included in the teaching objectives.

Second, as to the curriculum aspect, the university should optimize the setting of courses through the effective combination of compulsory courses and optional courses. Compulsory courses include College English Integrated Course and College English Listening and Speaking Course. In order to enhance the students' English teaching ability and cultivate more competent versatile teachers for elementary schools, the university provides students with some practical optional courses, such as Phonetics of English, English Stick Figures, Multimedia Courseware Design, English Teaching Methodology, The Organization and Management of English Teaching, Psychology of English Education, etc. At the same time, the university develops the second classroom for students and regularly provides students the opportunity to observe English teaching of experienced teachers from elementary schools. Students can simulate English teaching in the class and obtain sound advice. Above all, the curriculum is the integration of English basic courses and pedagogical courses. Meanwhile, English practical teaching is emphasized to enhance students' professional English skills.

Third, in terms of professional training, teachers should focus on enhancing students' English language learning ability, encouraging deep learning, and promoting advanced way of thinking. In the preprofessional cultivation of English competencies, students' oral ability should get strengthened, especially English pronunciation and intonation. Teachers should lead students to excavate the cultural connotations of English materials, express opinion critically, and develop their own values. They can adopt various English teaching methods, such as 
flipped class, situational teaching method, heuristic teaching method, inquiry teaching method, etc. The whole teaching process should be student-centered. Through the combination of online and offline teaching, students' learning autonomy will be activated. Meanwhile, elements of ideology and politics are integrated into English teaching to arouse students' enthusiasm for rural education. Besides, the university invites some English teaching experts to communicate with students in order to enhance their English teaching ability. Students are suggested to have group discussions on the teaching design of certain English materials, then make the courseware or mini-lecture, and finally give teaching demonstrations. After that, they will watch related excellent courses, and reflect on their drawbacks, by this way they can not only deeply understand and grasp English teaching methods from the practical level, but also grow faster as the future versatile teachers of elementary schools.

Fourth, assessment methods should be diversified. Only the mid-term exam and the final exam are not enough to measure students' performance. Cheng \& Zhao (2016) concluded students' key competencies in English as the following: language competence, cultural character, thinking quality and learning ability. Those key competencies provide references for evaluating students' performances. The assessment should be comprehensive. It should not only involve students' academic performance, but also the development of their competencies. In the aspect of academic performance, assessment of the learning process should be taken seriously. Teachers can adopt multiple evaluation system, such as self-evaluation, peer evaluation, in-class quizzes, oral assessment, etc. Data collected from leaning platforms should also be considered. As to the development of students' competencies, assessment should focus on students' learning behaviors, cognitive and affective attitude and cultural awareness. Teachers can make assessment through observations, questionnaires, interviews and other practical methods.

\section{Conclusion}

With the implementation of the rural vitalization strategy, the study of preprofessional cultivation strategies for English competencies of elementary school versatile teachers can provide some enlightenment on the cultivation of talents, thus providing powerful guarantee for English education of rural elementary schools in the future. The research on this topic has obtained some achievements so far. As the research perspective is quite new, there will be a much broader researching space for scholars to explore. It is also hoped that researches in this field will be more systematic and comprehensive.

\section{Funding}

The thesis is the research result of Baoding Education Science Planning Project: Preprofessional Cultivation Strategies for English Competencies of Elementary School Versatile Teachers under Rural Revitalization. Project number: 201059. 


\section{Conflicts of Interest}

The authors declare no conflicts of interest regarding the publication of this paper.

\section{References}

Chen, C. Y., \& Liao W. Q. (2019). Government-Supported Targeted-Area Teacher Education Program for Primary School General Teachers: Origin, Status Quo and Future Development. Journal of Lingnan Normal University, 4, 1-8.

Cheng, X. T., \& Zhao, S. Q. (2016). On Students' Key Competency in English as a Foreign Language. Curriculum, Teaching Material and Method, 5, 79-86.

Guo, S. F., Tian, Y. Y., \& Zheng C. Q. (2019). Repositioning the Role and Function of Primary School Versatile Teachers in the Context of Rural Revitalization. Contemporary Education Sciences, 8, 52-56+83.

Sun, C. G., \& Wen, S. S. (2020). The Practical Needs and Localized Training Strategies of General Subject Teachers for Rural Primary Schools. The Modern Education Journal, $6,2-10$.

The Central Committee of the Communist Party of China (CPC) and the State Council (2018a). On Comprehensively Deepening the Reform of Teaching Staff Construction in the New Era. http://www.gov.cn/zhengce/2018-01/31/content_5262659.htm

The Central Committee of the Communist Party of China (CPC) and the State Council (2018b). National Rural Vitalization Strategic Plan (2018-2022). http://www.gov.cn/zhengce/2018-09/26/content_5325534.htm

The Central Committee of the Communist Party of China (CPC) and the State Council (2018c). No. 1 Central Document. http://www.gov.cn/xinwen/2018-02/04/content_5263807.htm

Xi, J. P. (2017). Secure a Decisive Victory in Building a Moderately Prosperous Society in All Respects and Strive for the Great Success of Socialism with Chinese Characteristics for a New Era. The 19th National Congress of the Communist Party of China, 18 October 2017.

https://language.chinadaily.com.cn/a/201711/06/WS5d034782a3103dbf1432840b.html

Xiao, H. Y., \& Wu, X. M. (2020). The Preprofessional Cultivation of Versatile Teachers in Rural Primary Schools-Taking Ji'an Vocational and Technical College as an Example. Cultural and Educational Information, 26, 99-100+152.

Yang, X. B. (2019). Difficulties in Educational Program for General Teachers for Rural Primary Schools and Integrating Strategies-with Normal College of Jishou University as an Example. Journal of Jilin Teachers Institute of Engineering and Technology, 10, 54-57.

Yu, X. H., \& Yang, X. W. (2018). Problems and Countermeasures: How to Cultivate Versatile Teachers for "Beautiful Rural Construction". Educational Science Research, 10, $81-85$. 